\title{
Effects of predator odour on antipredator responses of Nile tilapia
}

\section{Caio Akira Miyai *, Fábio Henrique Carretero Sanches, Cândido Ferreira Pinho-Neto, Rodrigo Egydio Barreto}

Departamento de Fisiologia, Instituto de Biociências, UNESP, Rubião Jr. s/n, 18618-970 Botucatu, São Paulo, Brazil

\section{H I G H L I G H T S}

- Predator odour induce anti-predator behaviour.

- Predator odour induce an increase in ventilation rate.

- Increasing of ventilation rate to predator odour prepare Nile tilapia for 'fight or flight'.

- Predator odour did not activate the hypothalamic-pituitary-interrenal axis.

\section{A R T I C L E I N F O}

\section{Article history:}

Received 1 April 2016

Received in revised form 23 June 2016

Accepted 27 June 2016

Available online 28 June 2016

\section{Keywords:}

Chemical cues

Kairomone

Ventilation rate

Cortisol

Glucose

Locomotion

\begin{abstract}
A B S T R A C T
Several fish species exhibit antipredator responses when exposed to chemicals which indicate risk of predation One such substance is the scent of a predator (a kairomone) that may induce defensive responses in a potential prey. In the present study, we show that chemical cues (odour) from predator fish induce antipredator and stress responses in Nile tilapia. When exposed to predator odour, Nile tilapia decreased activity and increased ventilation rate (VR), but no increase in plasma levels of cortisol and glucose was found. Although the hypothalamicpituitary-interrenal axis (HPI axis) was not activated, an increase in ventilation is a fast response which can provide the fish enough oxygen for a 'fight or flight' event when facing a predator. Thus, this respiratory response suggests an anticipated adjustment in order to prepare the body for a defensive response, such as escaping, irrespective of HPI axis activation.
\end{abstract}

(c) 2016 Elsevier Inc. All rights reserved.

\section{Introduction}

In predator-prey interactions, the ability to recognize in advance the threat of a potential predator plays a key role in the survival of prey for any animal species [1]. Several fishes exhibit defensive responses when exposed to chemical cues that indicate predation risk [2]. These cues are well-documented as perceived stressors in fish [2-5] and can evoke a coordinated set of behavioural and physiological responses to cope with the threat, enabling the animal to maintain its homeostasis [5]. These cues can be derived from injured conspecifics, (alarm cues [2,6] conspecific blood [7]), dead conspecifics [8], disturbed and non-injured conspecifics [9], injured heterospecific sympatric species [3] or predator odours (kairomones $[10,11]$ ). In the case of predator chemical cues, diet may interfere with detection of predators; for instance, prey may detect a predator's odour more easily, as evidenced by most drastic antipredator responses after a predator has fed on conspecific prey $[12,13]$.

To avoid predation, fish have evolved many strategies to deal with such pressures [14]. In these strategies, prey may elicit behavioural

\footnotetext{
* Corresponding author.

E-mail address: caio_miyai@hotmail.com (C.A. Miyai).
}

responses, reducing the risk of detection by decreasing locomotor activity [15] or being immobile $[16,17]$. Further, to escape from a predator after being detected, prey may migrate [18], flee [19] or seek refuge [20-22]. One common antipredator fish behaviour in response to predator chemical cues is a decrease in swimming activity $[6,15,21,23]$. Minimizing locomotor activity can reduce water vibrations and detection by predators, increasing prey survival chances $[3,15]$.

Although behavioural responses in fish are generally observed when predator odour is present, physiological responses are also required to overcome the threat of predation [24]. These responses have been broadly described as primary, secondary, or tertiary [5]. Primary responses involve some initial neuroendocrine feedbacks after sympathetic autonomic nervous system activation, resulting in catecholamine release from the chromaffin tissue (hypothalamic-sympatheticchromaffin axis; HSC) [25], and/or the hypothalamic-pituitaryinterrenal (HPI) axis stimulation, culminating in discharge of corticosteroid hormones (e.g. cortisol) into the circulation [26,27]. This is accompanied by rapid cardiorespiratory adjustments $[5,28]$ as VR increases $[5,6,29]$. Secondary responses occur when stressors related to predation risk persist and are characterized by metabolic changes, such as increased plasma glucose levels $[5,26,30]$. Additionally, tertiary responses 
may occur in chronic stress situations, constricting the animal's wellbeing, affecting growth, resistance to disease and reproductive capacity [5,31]. In this context, previous studies have reported antipredator behaviour $[9,11,19,20]$, VR increase [29,32,33], cortisol release [27,34,35] and enhanced metabolic response [36-38] in fish exposed to a predator cue. However, none of these provide a link between primary (antipredator behaviour, and increase of VR and plasma cortisol) and secondary responses (increase of plasma glucose).

We selected the Nile tilapia Oreochromis niloticus (Linnaeus, 1758; Acanthopterygii; Perciformes; Cichlidae) as our experimental model, a cichlid fish species that visually recognizes and executes antipredator behaviour in the presence of predator fish $[39,40]$ and responds to chemical alarm cues [6,41]. Furthermore, this species also exhibits varied responses to different stressors, such as increasing VR, plasma cortisol and glucose levels $[6,42,43]$. Thus, we performed three experiments to further investigate the hypothesis that Nile tilapia submitted to the odour of a natural predator which had been fed tilapia, the African catfish Clarias gariepinus (Burchell, 1822; Ostariophysi; Siluriformes; Clariidae), could detect and recognize these chemical cues as a predation risk and respond accordingly both behavioural and physiologically.

\section{Material and methods}

\subsection{Fish and stock conditions}

Juvenile Nile tilapias were provided by a commercial fish farmer and were kept in three distinct $310 \mathrm{~L}$ tanks. Fish were immature, without sex differentiation, with a (mean \pm SD) standard length of $6.37 \pm 0.21 \mathrm{~cm}$ and a mass of $8.60 \pm 1.06 \mathrm{~g}$. We used as a natural predator the African catfish, kept in a separate $310 \mathrm{~L}$ tank, without sex differentiation. As non-predator control, we used the common carp (Cyprinus carpio; Linnaeus, 1758; Ostariophysi; Cypriniformes; Cyprinidae), kept in a separate 310-L tank), also without sex differentiation. Predator and non-predator specimens were obtained from a commercial fish farmer. All fishes were maintained in indoor tanks in appropriate stock density $(0.5 \mathrm{~g} / \mathrm{L})$ for at least 30 days prior to experimentation and fed commercial fish food to satiation once a day (Guabi - Pira 32\% protein). Temperature in all tanks was $26 \pm 1.5^{\circ} \mathrm{C}$, in which ammonia $(<0.5 \mathrm{ppm})$ and nitrite $(<0.05 \mathrm{ppm})$ levels were controlled by biological filtration and constant water changes (dechlorinated tap water). The photoperiod was kept constant (12L:12D). None of Nile tilapia had previous contact with either African catfish or common carp.

\subsection{Experimental design}

In experiment 1 , we tested the effect of predator odour on prey swimming activity. For such purpose, Nile tilapia were exposed to $50 \mathrm{~mL}$ of natural predator odour (African catfish) that had been fed tilapia, $50 \mathrm{~mL}$ of non-predator odour (common carp, used as control for the predator odour), or $50 \mathrm{~mL}$ of water control. Based on similar studies conducted in other fish species that considered changes in swimming activity as an antipredator response $[6,15,21,23]$, locomotion decrease due to African catfish odour indicated that Nile tilapia recognized this chemical as a predation risk, inducing a typical behavioural response. Thereafter, we conducted a second experiment, to investigate the effect of predator odour on VR as an indicator of physiological responses. We exposed Nile tilapia to either $50 \mathrm{~mL}$ of predator odour or $50 \mathrm{~mL}$ of water control. A rapid VR response to predator odour indicated the Nile tilapia sympathetic autonomic nervous system had been activated and the primary responses (catecholamine and corticosteroid hormones release) had occurred. Results from experiments 1 and 2 provide evidence to hypothesize that predator odour might have stimulated the Nile tilapia HPI axis, thus causing the release of corticosteroid hormones and increased plasma glucose levels. In light of this, we carried out a third experiment in order to evaluate the effect of predator odour on plasma levels of cortisol and glucose over time, in which Nile tilapia were exposed to $50 \mathrm{~mL}$ of predator odour or $50 \mathrm{~mL}$ of water control at $0 \mathrm{~min}, 15 \mathrm{~min}, 30 \mathrm{~min}, 60 \mathrm{~min}, 120 \mathrm{~min}$ and $240 \mathrm{~min}$ after initial exposure. An increase in cortisol and glucose plasma levels would indicate the HPI axis activation and metabolic responses, respectively.

\subsection{Predator and non-predator odour collection}

Two African Catfish (standard length: $16.20 \mathrm{~cm}$ and $16.60 \mathrm{~cm}$; weight: $35.93 \mathrm{~g}$ and $43.75 \mathrm{~g}$, respectively) were individually housed for six days in $42 \mathrm{~L}$ aquaria $(40 \times 30 \times 35 \mathrm{~cm})$ with temperature, photoperiod and water conditions similar to those in the stock. African catfish are active, piscivorous and natural predators of Nile tilapia [44-47] and, to ensure that all predators had been fed and subjected to a standardized procedure, fish were fed twice during this period (second and fourth day) with Nile tilapia fresh fillets (with skin, but scaleless; $3 \%$ of African catfish weight per feeding). African catfish necessitate $40 \mathrm{~h}$ at a temperature of $30^{\circ} \mathrm{C}$ to completely evacuate their gut [48], so on the sixth day (i.e. $48 \mathrm{~h}$ after the catfish were last fed, to ensure stomachs were empty), fish were rinsed, transferred and individually housed in $22 \mathrm{~L}$ aquaria $(40 \times 24 \times 23 \mathrm{~cm}$; stocking density $2 \mathrm{~g} / \mathrm{L})$ containing fresh dechlorinated tap water and an air stone, but no filter, and kept for $24 \mathrm{~h}$, without food. After this period, each fish was removed and the water was filtered (to avoid any visible particles), stored into $50 \mathrm{~mL}$ aliquots and frozen at $-20^{\circ} \mathrm{C}$ until required for testing. Nonpredator odour was obtained from two common carp (standard length: $15.40 \mathrm{~cm}$ and $14.20 \mathrm{~cm}$; weight: $88.43 \mathrm{~g}$ and $77.45 \mathrm{~g}$, respectively; stocking density $4 \mathrm{~g} / \mathrm{L}$ ), kept under the same conditions used to collect predator odour. Carp odour was diluted in fresh dechlorinated tap water to attain the catfish odour concentration. Instead of Nile tilapia fillets, carp were fed with the same commercial fish food used in stock conditions (second and fourth day; $3 \%$ of carp weight per feeding; Guabi - Pira 32\% protein). Procedures were adapted from Ferrari et al. [11].

\subsection{Experiment 1}

We evaluated the effect of predator odour on Nile tilapia behaviour. Fish were exposed to $50 \mathrm{~mL}$ of one of the following chemical cues: odour of predator fed on tilapia $(n=10)$; odour of non-predator, used as control for predator odour $(n=12)$; or deionized water $(n=9)$ as a control for presence/absence of chemical cues and lab conditions, totalling 31 individuals. Fish from the stock population were randomly chosen, individually housed and acclimated in glass tanks $(40 \times 24 \times 23 \mathrm{~cm} ; 22 \mathrm{~L})$ for $60 \mathrm{~h}$ prior to experimentation. Each aquarium was supplied with constant aeration and water temperature was maintained at $26 \pm$ $1.5^{\circ} \mathrm{C}$. Ammonia $(<0.5 \mathrm{ppm})$ and nitrite $(<0.05 \mathrm{ppm})$ levels were controlled by water changes and the photoperiod was kept constant (12 L:12D). Food was offered once a day, but not on the day of the experiment. After the acclimation period, baseline of behaviour was recorded during $5 \mathrm{~min}$ and for another $5 \mathrm{~min}$ after inserting one of the stimuli into the experimental aquaria. The assessed behavioural response was locomotion, measured by the number of quadrant changes. Each aquarium had on its back a polystyrene plate divided in nine quadrants $(13.3 \times 8.0 \mathrm{~cm})$. A quadrant change was considered when at least $75 \%$ of the fish's body crossed the line [7]. Locomotion values were considered as the deviation from the initial condition (post-stimulus minus baseline). All movements were quantified using camcorders, set up $1.5 \mathrm{~m}$ in front of the experimental aquaria.

\subsection{Experiment 2}

In experiment 1 , we found evidence to support the hypothesis that Nile tilapia recognize predator odour as a predation risk by decreasing their swimming activity. Therefore, we conducted a second experiment to investigate whether Nile tilapia VR would increase in response to predator odour. Fish were individually housed and acclimated in the 
same setup as described in the previous experiment. We exposed Nile tilapia to $50 \mathrm{~mL}$ of odour from a predator fed on tilapia or $50 \mathrm{~mL}$ of deionized water. Baseline VR was measured for 5 min before stimuli insertion, and then for another 5 min after stimulus introduction ( $n=14$ for predator odour; $\mathrm{n}=16$ for deionized water; 30 fish total). VR was estimated by counting opercular beats $(\mathrm{OB})$ for $15 \mathrm{~s}$ and multiplying by 4 to obtain OB per minute (ob/min). Five observations were made over $5 \mathrm{~min}$ for each period (baseline and post-stimulus), and then averaged. Values were considered as the deviation from the initial condition (post-stimulus minus baseline).

\subsection{Experiment 3}

Well-established indicators of fish stress responses to predator cues include increase in VR, cortisol and glucose plasma levels. From results obtained in experiments 1 and 2, we hypothesize that predator odour caused primary stress responses by release of corticosteroid hormones, thus leading to increased plasma glucose level. We then tested the effect of predator odour on plasma levels of cortisol and glucose over time. Fish were kept and acclimated in the same experimental aquarium setup as described for experiment 1 . Two chemical cues were used here, either odour of a predator fed on tilapia or deionized water. Cortisol and glucose levels were measured at $0 \mathrm{~min}, 15 \mathrm{~min}, 30 \mathrm{~min}, 60 \mathrm{~min}$, $120 \mathrm{~min}$ and $240 \mathrm{~min}$ after initial exposure $(\mathrm{n}=10$ independent fish for each stimulus and each interval; 120 fish total). Plasma levels of cortisol and glucose were analysed from blood samples. Each fish was gently removed from the experimental aquaria and placed in a container of benzocaine solution $(80 \mathrm{mg} / \mathrm{L})$. After partial anaesthesia [49], blood was sampled by cardiac puncture using heparinized insulin syringes $(1 \mathrm{~mL})$ to prevent blood clotting. Blood was centrifuged at $754.65 \mathrm{RCF}$ (g) for 10 min and plasma was collected and frozen at $-20^{\circ} \mathrm{C}$ until required for analysis. Plasma cortisol levels were determined with a commercial enzyme-linked immunosorbent assay ELISA kit (DRG®, International Inc., Cortisol Enzyme Immunoassay Kit) specific for cortisol testing. The Elisa assay has been validated and considered a precise and accurate procedure to assess cortisol in teleost fish [50-52], including Nile tilapia [53]. Plasma glucose levels were assessed by the colorimetric method of Trinder [54].

\subsection{Data analyses}

Data were tested for homoscedasticity by Levene's test and for normality by Shapiro-Wilk's W test. Locomotion values were considered heteroscedastic and not normally distributed even after transformation. We calculated deviation from the initial condition (post-stimulus minus baseline) and the difference in changes between pairs of treatments (three comparisons: predator odour $\times$ water control; predator odour $\times$ non-predator odour; water control $\times$ non-predator) were analysed by separate Mann-Whitney $U$ test [55]. We used the modified Bonferroni procedure [56] to control the false positive error rate (type 1 error) when multiple significant comparisons are performed. The modified Bonferroni procedure [(alpha $*$ treatments -1 ) / number of comparisons] attests that corrections to the family-wise error rate can be done when the number of comparisons exceeds the number of treatments minus 1 [56]. In experiment 1, we had a total of three treatments in which three comparisons were made; therefore, the family-wise error rate was held to $\mathrm{p}<0.033$. Ventilation rate data were also heteroscedastic and not normally distributed, so we also used the Mann-Whitney $U$ test in which statistical differences were considered significant when $\mathrm{p}<0.05$. Plasma levels of cortisol and glucose were normal and homoscedastic, analysed by an independent Student's t-test at each time point, since we had independent groups. Outlying data were identified and removed for locomotion (5) and VR (2), identified by values outside the range of the mean to which two standard deviations were added or subtracted. Residuals were removed in the top or bottom $2.5 \%$ of the distribution [57].

\subsection{Ethical note}

This study complied with the Ethical Principles in Animal Research adopted by the National Council for the Control of Animal Experimentation - Brazil (CONCEA - Conselho Nacional de Controle de Experimentacão Animal - Brazil) and was approved by the Ethical Committee for Animal Research from the Instituto de Biociências/ UNESP (CEUA - Comissão de Ética no Uso de Animais), protocol 237.

\section{Results}

\subsection{Behavioural responses}

Fig. 1 represents three independent Mann-Whitney $U$ tests used to compare each possible treatment combination. Presence of non-predator odour did not affect locomotor activity compared to water control (Mann-Whitney $U$ test, $\mathrm{Z}=-0.213, \mathrm{p}=0.862$ ), and no difference was observed between predator and non-predator odour (Fig. 1C; Mann-Whitney $U$ test, $Z=1.483 \mathrm{p}=0.149$ ), while presence of odour from predator fed on tilapia fillets caused a decrease in swimming activity compared to water control (Fig. 1D; Mann-Whitney $U$ test, $Z=2.204$ $\mathrm{p}=0.027$ ).

\subsection{Stress responses}

Physiological responses to the chemical cue are presented in Fig. 2. Predator odour increased VR compared to eluent control (Fig. 2A; Mann-Whitney U test, $\mathrm{Z}=-2.411, \mathrm{p}=0.015)$. Both plasma cortisol (Fig. 2B; Student's t-test, $\mathrm{p}>0.05$ ) and glucose (Fig. 2C; Student's $t$ test, $\mathrm{p}>0.05$ ) levels were not affected by predator odour at any time point after exposure to chemical stimuli.

\section{Discussion}

In the present study, we showed that predator odour induces antipredator behaviour and physiological responses in Nile tilapia. When exposed to predator odour, the model decreases locomotion and increases VR. However, no increase was found in plasma levels of cortisol and glucose. Although the HPI axis was not activated, the respiratory alteration may have anticipated a physiological adjustment to prepare the

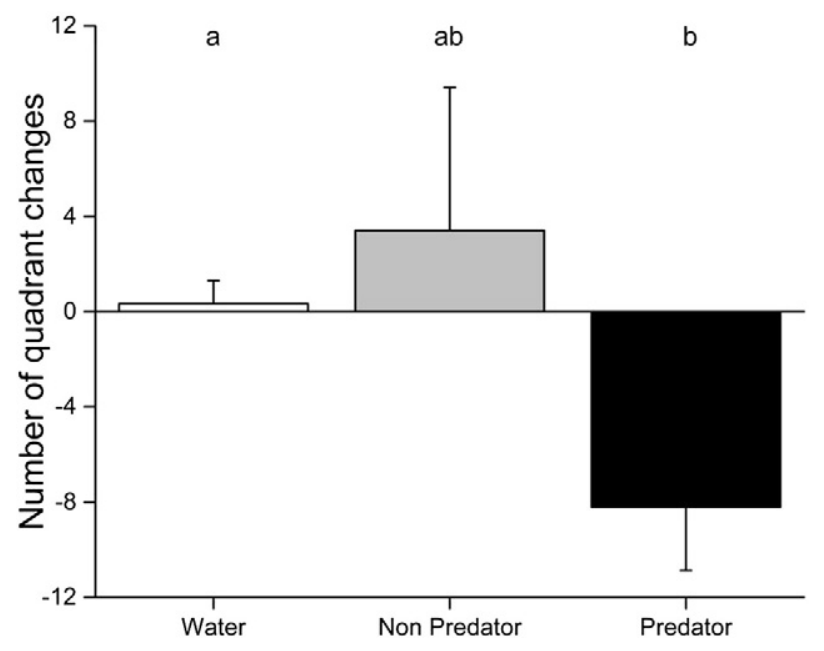

Fig. 1. Behavioural response (locomotion) of Nile tilapia to chemical cues. Number of quadrants changes in fish exposed to non-predator odour compared to deionized water (Mann-Whitney $U$ test, $\mathrm{p}=0.862$ ), non-predator odour compared to predator odour (Mann-Whitney $U$ test, $\mathrm{p}=0.149$ ) and predator odour compared to deionized water (Mann-Whitney $U$ test, $\mathrm{p}=0.027$ ). Locomotion values were considered as the deviation from the initial condition (post-stimulus minus baseline). Data represent mean \pm SE and different letters indicate significant difference at $\mathrm{p}<0.033$ (see text for details). 

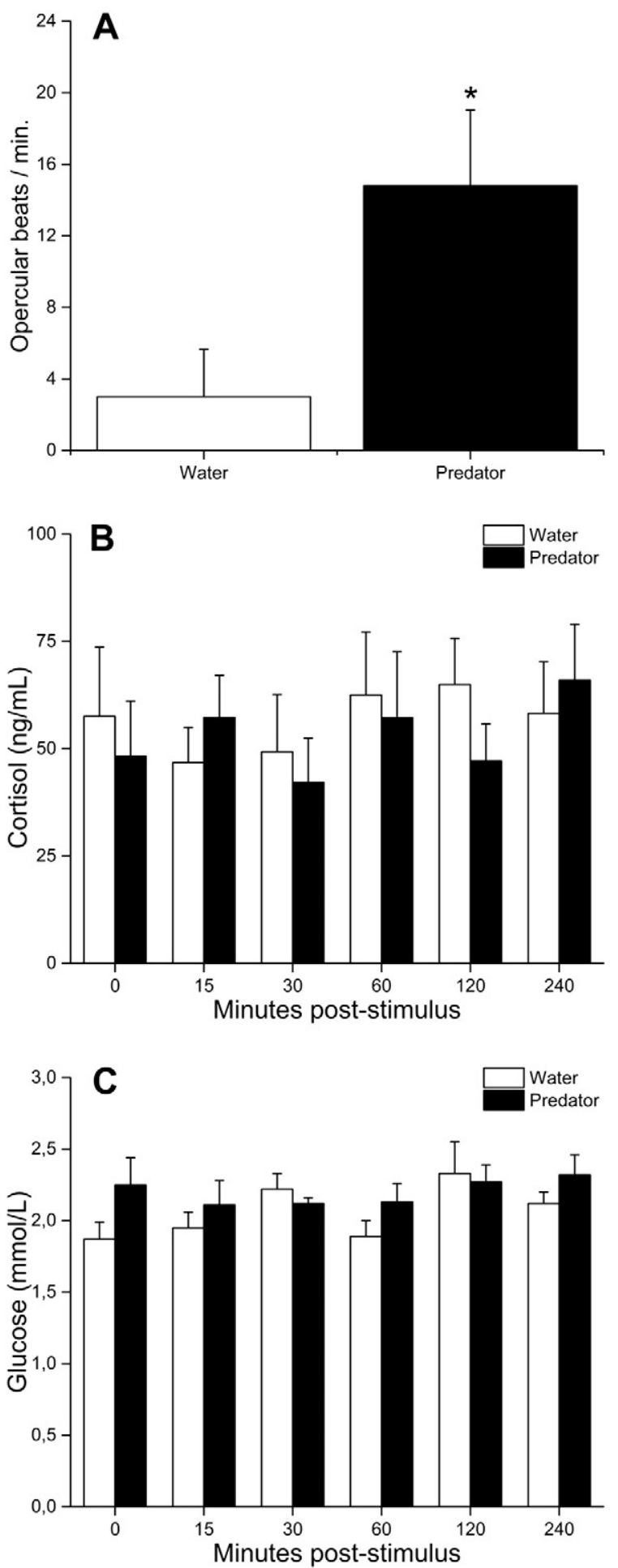

Fig. 2. Stress responses of Nile tilapia to chemical cues. Ventilation rate in fish exposed to predator odour and control (A; Mann-Whitney $U$ test; $Z=-2.411, \mathrm{p}=0.015$ ); Values were considered as the deviation from the initial condition (post-stimulus minus baseline). Cortisol concentration in blood plasma (B; Student's $t$-test, $\mathrm{p}>0.05$ ); and glucose concentration in blood plasma ( $C$; Student's $t$-test, $\mathrm{p}>0.05$ ) in fish exposed to predator odour and control. Data represent mean \pm SE and asterisk indicates significant difference between treatments at $\mathrm{p}<0.05$.

body for a defensive and highly metabolically demanding response, such as escaping or facing the predator [32,58-60].

Some studies have reported antipredator responses in fish prey subjected to the odour of predators fed on prey conspecifics [12,61-63], or even chemical cues from predator faeces [64-67]. In both cases, prey efficiently recognized the predator's diet and responded more drastically to predation risk when the predator ate prey conspecifics $[12,14]$. Therefore, these studies showed well-established evidences that prey alarm cues are chemically preserved in the predator, even when passing through the digestive system [68]. African catfish odour donors had their gut emptied before odour collection, suggesting that chemical cues from prey could be derived from urine [69] or mucus [70], for example. Our findings indicate that no active predation events were needed (direct release of prey alarm cues in the water), not even the release of predator faeces or other intestinal by-products as chemical cues, to elicit antipredator responses in Nile tilapia.

Locomotion of Nile tilapia exposed to predator odour was evaluated as an indicator of antipredator response. Swimming activity is strongly affected by chemical cues that indicate predation risk and the reduction of locomotion is considered a defensive response $[2,41,71]$. In our study, no difference was observed between non-predator and water control, as expected. In contrast, swimming activity was decreased by exposure to chemical stimulus from the predator fed on Nile tilapia, according to other species reports, such as in the fathead minnow Pimephales promelas; [12], the brook charr Salvelinus fontinalis; [61] and the Atlantic salmon Salmo salar; [64]. This decrease in locomotion after recognition of a chemical cue which indicates risk of predation results in lower detection $[12,14,22]$ and predator encounter probabilities $[1,10,24,72,73]$.

After the alteration in behaviour, we evaluated the effects on physiological responses using deionized water as control. Our baseline values of VR and blood plasma concentrations of cortisol and glucose showed an unstressed baseline condition. Herein, fish were approximately $6.4 \mathrm{~cm}$ long with a baseline VR of approximately $116 \mathrm{ob} / \mathrm{min}$, very close to non-stressed values found in studies in which Nile tilapia were approximately $6.8 \mathrm{~cm}$ long and showed rates of approximately $118 \mathrm{ob} / \mathrm{min}$ [74] and 117-124 ob/min [39]. Mean baseline cortisol level was $50.01 \mathrm{ng} / \mathrm{mL}$, in the range of 5.0 and $60.0 \mathrm{ng} / \mathrm{mL}[42,75-78]$, previously described as pertaining to a non-stressed situation. Mean baseline glucose level was $2.07 \mathrm{mmol} / \mathrm{L}$, within the range reported by others studies, between 1.91 and $7.21 \mathrm{mmol} / \mathrm{L}$, also demonstrating a non-stressed situation $[6,43,79]$. All baseline physiological values showed in the present study are consistent with reports mentioned previously and it is important to validate the unstressed baseline condition in which the Nile tilapia started from. The fact that we found no difference in cortisol and glucose levels in Nile tilapia after exposure to predator odour means that the HPI axis was not activated, showing that the only physiological response reported in this study was elevation of VR.

Although the HPI axis was not activated due to exposure to odour of a predator fed on prey conspecifics, Nile tilapia had a decrease in locomotion and an increase in VR when subjected to this chemical cue. Decrease in swimming activity reduces water vibrations that could alert predators, resulting in a lower probability of detection and encounter, thus increasing prey survival odds $[2,7,11,21]$. Non-activation of the HPI axis makes sense, since in an aquatic environment chemical perception of predators is facilitated [2]. An increase of cortisol, followed by an increase of glucose every time a predator was noticed, could be considered a metabolic fright response [37] and a high-energy demanding process $[5,26]$, leading to a nonlethal energetic cost condition to the prey $[37,80,81]$. Furthermore, the persistence of a sustained/chronic HPI axis activation could elicit some tertiary stress responses such as reduction of growth rates $[24,26,82]$, reproductive capacity $[5,26]$ and, ultimately, fitness [83].

Surprisingly, increase in plasma catecholamines in response to chemical predator cues in fish has not been described yet. In fish stress condition, catecholamine release might be the major physiological response when an increase in plasma cortisol does not occur [84], since it induces hyperventilation, increases gill diffusing capacity, stimulates blood oxygen transport capacity, and allows a greater uptake in order to support adequate oxygen levels in the blood and tissues [25,84]. Thus, the increase in VR should be enough to augment oxygen uptake and prepare the body for a possible and sudden aerobic activity, like 
escaping $[32,33,85,86]$, with minimum but sufficient metabolic adjustment after the first detection of predation risk [37].

This study is an attempt to investigate more deeply the combination of behavioural and physiological reactions of fish in response to chemical stimuli of a predator recently fed on conspecifics. As already shown by Rehnberg and Schreck [30], our results also indicate that a tight linkage between behavioural and prey HPI axis activation due to predator chemical stimuli does not necessarily co-occur. We conclude that Nile tilapia exposed to odour of a predator fed a tilapia diet elicit behavioural and physiological responses by reducing locomotion and increasing VR, but no change in plasma levels of cortisol and glucose occurs. Future studies should take into account analysis of catecholamine levels and examine if activation of the prey HPI axis could happen when predation risk is more intense; e.g. in situations where chemical (predator odour and prey alarm cues) and predator visual stimuli are coupled simultaneously.

\section{Acknowledgements}

The authors wish to thank the technical support from A.L.C. Bovolato. FAPESP (Fundação de Amparo à Pesquisa do Estado de São Paulo, Brazil) supported this research (Process: 2010/11319-0), as well as C.A. Miyai via a master's degree scholarship (Process: 2011/ 03216-9).

\section{References}

[1] Defense against predators, in: J.A. Endler, M.E. Feder, G.V. Lauder (Eds.), PredatorPrey Relationships Perspect. Approaches from Study Low. Vertebr. University of Chicago, Chicago 1986, pp. 109-134.

[2] D.P. Chivers, R.J.F. Smith, Chemical alarm signaling in aquatic predator-prey systems: a review and prospectus, Ecoscience 5 (1998) 338-352.

[3] L.B. Kats, L.M. Dill, The scent of death: chemosensory assessment of predation risk by prey animals, Ecoscience 5 (1998) 361-394, http://dx.doi.org/10.2307/ 42902443.

[4] M.C.O. Ferrari, B.D. Wisenden, D.P. Chivers, Chemical ecology of predator-prey interactions in aquatic ecosystems: a review and prospectus, Can. J. Zool. 88 (2010) 698-724, http://dx.doi.org/10.1139/Z10-029.

[5] B.A. Barton, Stress in fishes: a diversity of responses with particular reference to changes in circulating corticosteroids, Integr. Comp. Biol. 42 (2002) 517-525, http://dx.doi.org/10.1093/icb/42.3.517.

[6] F.H.C. Sanches, C.A. Miyai, C.F. Pinho-Neto, R.E. Barreto, Stress responses to chemical alarm cues in Nile tilapia, Physiol. Behav. 149 (2015) 8-13, http://dx.doi.org/10. 1016/j.physbeh.2015.05.010.

[7] R.E. Barreto, C.A. Miyai, F.H.C. Sanches, P.C. Giaquinto, H.C. Delicio, G.L. Volpato, Blood cues induce antipredator behavior in Nile tilapia conspecifics, PLoS One (2013)http://dx.doi.org/10.1371/journal.pone.0054642.

[8] T.A. Oliveira, G. Koakoski, A.C. da Motta, A.L. Piato, R.E. Barreto, G.L. Volpato, L.J.G. Barcellos, Death-associated odors induce stress in zebrafish, Horm. Behav. 65 (2014) 340-344, http://dx.doi.org/10.1016/j.yhbeh.2014.02.009.

[9] L. Jordao, G. Volpato, Chemical transfer of warning information in non-injured fish, Behaviour 137 (2000) 681-690.

[10] J.W. Petranka, L.B. Kats, A. Sih, Predator-prey interactions among fish and larval amphibians: use of chemical cues to detect predatory fish, Anim. Behav. 35 (1987) 420-425, http://dx.doi.org/10.1016/S0003-3472(87)80266-X.

[11] M.C.O. Ferrari, F. Messier, D.P. Chivers, The nose knows: minnows determine predator proximity and density through detection of predator odours, Anim. Behav. 72 (2006) 927-932, http://dx.doi.org/10.1016/j.anbehav.2006.03.001.

[12] A. Mathis, R.J.F. Smith, Fathead minnow, Pimephales promelas, learn to recognize northern pike, Esox lucius, as predators on the basis of chemical stimuli from minnows in the pike's diet, Anim. Behav. 46 (1993) 645-656, http://dx.doi.org/10. 1006/anbe.1993.1241.

[13] H. Hirvonen, E. Ranta, J. Piironen, A. Laurila, N. Peuhkuri, Behavioural responses of naive Arctic charr young to chemical cues from salmonid and non-salmonid fish, Oikos 88 (2000) 191-199, http://dx.doi.org/10.1034/j.1600-0706.2000.880121.x.

[14] J.G. Godin, Behavioural Ecology of Teleost Fishes, Oxford University Press, Oxford, 1997.

[15] A.B. Júnior, E. Magalhães, A. Hoffmann, L. Ide, Conspecific and heterospecific alarm substance induces behavioral responses in piau fish Leporinus piau, Acta Ethol. 13 (2010) 119-126, http://dx.doi.org/10.1007/s10211-010-0081-6.

[16] J.F. Savino, R.A. Stein, Behavioural interactions between fish predators and their prey: effects of plant density, Anim. Behav. 37 (1989) 311-321, http://dx.doi.org/ 10.1016/0003-3472(89)90120-6.

[17] R.E. Barreto, A. Barbosa-Júnior, E.C. Urbinati, A. Hoffmann, Cortisol influences the antipredator behavior induced by chemical alarm cues in the Frillfin goby, Horm. Behav. 65 (2014) 394-400, http://dx.doi.org/10.1016/j.yhbeh.2014.03.007.
[18] O. Pen, B.A. Berejikian, M.E. Moore, S.J. Jeffries, Predator - prey interactions between harbor seals and migrating steelhead trout smolts revealed by acoustic telemetry, 543 (2016) 21-35, http://dx.doi.org/10.3354/meps11579.

[19] P. Domenici, Context-dependent variability in the components of fish escape response: integrating locomotor performance and behavior, J. Exp. Zool. Part A Ecol Genet. Physiol. 313 (A) (2010) 59-79, http://dx.doi.org/10.1002/jez.580.

[20] A.E. Magurran, Acquired recognition of predator odor in the European minnow (Phoxinus phoxinus), Ethology 82 (1989) 216-233, http://dx.doi.org/10.1111/j. 1439-0310.1989.tb00501.x.

[21] M. Lehtiniemi, Swim or hide : predator cues cause species specific reactions in young fish larvae, J. Fish Biol. 66 (2005) 1285-1299, http://dx.doi.org/10.1111/j. 1095-8649.2005.00681.x

[22] P. Eklöv, L. Persson, Species-specific antipredator capacities and prey refuges: interactions between piscivorous perch (Perca fluviatilis) and juvenile perch and roach (Rutilus rutilus), Behav. Ecol. Sociobiol. 37 (1995) 169-178.

[23] D. Milano, M. Lozada, H.E. Zagarese, Predator-induced reaction patterns of landlocked Galaxias maculatus to visual and chemical cues, Aquat. Ecol. 44 (2010) 741-748, http://dx.doi.org/10.1007/s10452-010-9312-1.

[24] S.L. Lima, L.M. Dill, Behavioral decisions made under the risk of predation: a review and prospectus, Can. J. Zool. 68 (1990) 619-640, http://dx.doi.org/10.1139/z90-092.

[25] S.G. Reid, N.J. Bernier, S.F. Perry, The adrenergic stress response in fish: control of catecholamine storage and release, 120 (1998) 1-27.

[26] E. Wendelaar, I. Introduction, C. Axis, B. Neuroendocrine, V. Stress, A. Hydromineral, E. Balance, A. Growth, B. Reproductive, The Stress Response in Fish, 77, 1997.

[27] L. José, G. Barcellos, F. Ritter, L. Carlos, R. Mezzalira, L. Bolognesi, A. Calliari, J. Finco, L. Cericato, Whole-body cortisol increases after direct and visual contact with a predator in zebrafish, Danio rerio 272 (2007) 774-778, http://dx.doi.org/10.1016/j. aquaculture.2007.09.002.

[28] L.J. Oulton, V. Haviland, C. Brown, Predator recognition in rainbowfish, Melanotaenia duboulayi, embryos, PLoS One 8 (2013) 8-11, http://dx.doi.org/10.1371/journal. pone.0076061.

[29] A.K. Gibson, A. Mathis, Opercular beat rate for rainbow darters Etheostoma caeruleum exposed to chemical stimuli from conspecific and heterospecific fishes, J. Fish Biol. 69 (2006) 224-232, http://dx.doi.org/10.1111/j.1095-8649.2006.01102. $\mathrm{x}$.

[30] B. Rehnberg, C. Schreck, Chemosensory detection of predators by coho salmon (Oncorhynchus kisutch): behavioural reaction and the physiological stress response, Can. J. Zool. 65 (1987) 481-485.

[31] G.A. Wedemeyer, B.A. Barton, D.J. McLeay, Stress and acclimation, in: C.B. Schreck, P.B. Moyle (Eds.), Methods Fish Biol, American Fisheries Society, Maryland 1990, pp. 451-489.

[32] L.A. Hawkins, J.D. Armstrong, A.E. Magurran, Predator-induced hyperventilation in wild and hatchery Atlantic salmon fry, J. Fish Biol.John Wiley \& Sons 2004 pp. 88-100, http://dx.doi.org/10.1111/j.1095-8649.2004.00543.x.

[33] L.A. Hawkins, A.E. Magurran, J.D. Armstrong, Innate abilities to distinguish between predator species and cue concentration in Atlantic salmon, Anim. Behav. 73 (2007) 1051-1057, http://dx.doi.org/10.1016/j.anbehav.2006.08.011.

[34] J.P. Breves, J.L. Specker, Cortisol stress response of juvenile winter flounder (Pseudopleuronectes americanus, Walbaum) to predators, J. Exp. Mar. Bio. Ecol. 325 (2005) 1-7, http://dx.doi.org/10.1016/j.jembe.2005.04.019.

[35] B.N. Harris, J.A. Carr, General and Comparative Endocrinology The role of the hypothalamus-pituitary-adrenal/interrenal axis in mediating predator-avoidance tradeoffs, Gen. Comp. Endocrinol. 230-231 (2016) 110-142, http://dx.doi.org/10.1016/j. ygcen.2016.04.006.

[36] T. Sunardi, J. Asaeda, Manatunge, Physiological responses of topmouth gudgeon, Pseudorasbora parva, to predator cues and variation of current velocity, Aquat Ecol. 41 (2007) 111-118, http://dx.doi.org/10.1007/s10452-006-9048-0.

[37] S.J. Cooke, J. Steinmetz, J.F. Degner, E.C. Grant, D.P. Philipp, Metabolic fright responses of different-sized largemouth bass (Micropterus salmoides) to two avian predators show variations in nonlethal energetic costs, Can. J. Zool. 81 (2003) 699-709, http://dx.doi.org/10.1139/z03-044.

[38] A.E. Hall, T.D. Clark, Seeing is believing: metabolism provides insight into threat perception for a prey species of coral reef fish, Anim. Behav. 115 (2016) 117-126, http://dx.doi.org/10.1016/j.anbehav.2016.03.008.

[39] R.E. Barreto, A.C. Luchiari, A.L. Marcondes, Ventilatory frequency indicates visual recognition of an allopatric predator in naive Nile tilapia, Behav. Process. 60 (2003) 235-239, http://dx.doi.org/10.1016/S0376-6357(02)00127-4.

[40] R.H.A. Freitas, G.L. Volpato, Behavioral response of Nile tilapia to an allopatric predator, Mar. Freshw. Behav. Physiol. 41 (2008) 267-272, http://dx.doi.org/10.1080/ 10236240802509767.

[41] R.E. Barreto, A.B. Júnior, A.C.C. Giassi, A. Hoffmann, The "club" cell and behavioural and physiological responses to chemical alarm cues in the Nile tilapia Mar. Freshw. Behav. Physiol. 43 (2010) 75-81, http://dx.doi.org/10.1080/ 10236241003654139

[42] R.E. Barreto, G.L. Volpato, Caution for using ventilatory frequency as an indicator of stress in fish, Behav. Process. 66 (2004) 43-51, http://dx.doi.org/10.1016/j.beproc. 2004.01.001.

[43] R.E. Barreto, G.L. Volpato, Stress responses of the fish Nile tilapia subjected to electroshock and social stressors, Brazilian J. Med. Biol. Res. 39 (2006) 1605-1612, http://dx.doi.org/10.1590/S0100-879X2006001200012.

[44] G. De Graaf, B. Banzoussi, Recruitment control of Nile tilapia, Oreochromis niloticus, by the African catfish, Clarias gariepinus (Burchell 1822)) and the African snakehead, Ophiocephalus obscuris. I. A biological analysis, 146 (1996).

[45] U.B. Wakil, Examinations of the stomach contents of two fish species (Clarias gariepinus and Oreochromis niloticus) in Lake Alau, North-Eastern Nigeria, Agric For. Fish 3 (2014) 405, http://dx.doi.org/10.11648/j.aff.20140305.23. 
[46] E. Trewavas, G.G. Teugels, Checklist of the Freshwater Fishes of Africa (CLOFFA) fourth ed. ORSTON MRAC, 1991

[47] G.A. Boulenger, The Fishes of the Nile, Hugh Ress Ltd, London, 1907.

[48] M.A.R. Hossain, G.S. Haylor, M.C.M. Beveridge, An evaluation of radiography in studies of gastric evacuation in African catfish fingerlings, 385 (1998) 379-385.

[49] A.M.M.C. Gontijo, R.E. Barreto, G. Speit, V.A.V. Reyes, G.L. Volpato, D.M.F. Salvadori, Anesthesia of fish with benzocaine does not interfere with comet assay results, Mutat. Res. Toxicol. Environ. Mutagen. 534 (2003) 165-172, http://dx.doi.org/10. 1016/S1383-5718(02)00276-0.

[50] T.D. Sink, R.T. Lochmann, K.A. Fecteau, Validation, use, and disadvantages of enzyme-linked immunosorbent assay kits for detection of cortisol in channel catfish largemouth bass, red pacu, and golden shiners, Fish Physiol. Biochem. 34 (2008) 95-101, http://dx.doi.org/10.1007/s10695-007-9150-9.

[51] T.P. Barry, A.F. Lapp, T.B. Kayes, J.A. Malison, Validation of a microtitre plate ELISA for measuring cortisol in fish and comparison of stress responses of rainbow trout ( $\mathrm{On}$ corhynchus mykiss) and lake trout (Salvelinus namaycush), Aquaculture 117 (1993) 351-363, http://dx.doi.org/10.1016/0044-8486(93)90331-R.

52] S.J. Lupica, J.W. Turner, Validation of enzyme-linked immunosorbent assay for measurement of faecal cortisol in fish, Aquac. Res. 40 (2009) 437-441, http://dx.doi.org/ 10.1111/j.1365-2109.2008.02112.x.

[53] T.L. Welker, C. Lim, M. Yildirim-Aksoy, P.H. Klesius, Growth, immune function, and disease and stress resistance of juvenile Nile tilapia (Oreochromis niloticus) fed graded levels of bovine lactoferrin, Aquaculture 262 (2007) 156-162, http://dx.doi.org/ 10.1016/j.aquaculture.2006.09.036

[54] P. Trinder, Determination of blood glucose using an oxidase-peroxidase system with a non-carcinogenic chromogen, J. Clin. Pathol. 22 (1969) 158-161, http://dx.doi.org/ 10.1136/jcp.22.2.158

[55] S. Siegel, N.J. Castellan, Nonparametric Statistics for the Behavioral Sciences, second ed. McGraw-Hill, New York, 1988

[56] G. Keppel, T.D. Wickens, Design and Analysis: A Researchers Handbook, fourth ed. Pearson, Upper Saddle River, NJ, 2004

[57] L. Wilkinson, G. Blank, C. Gruber, Desktop Data Analysis with Systat, Prentice-Hall, Englewood Cliffs, 1996

[58] S. Slos, R. Stoks, Predation risk induces stress proteins and reduces antioxidant defense, Funct. Ecol. 22 (2008) 637-642, http://dx.doi.org/10.1111/j.1365-2435. 2008.01424.x.

[59] C. Lydersen, K.M. Kovacs, Paralysis as a defense response to threatening stimuli in harp seals (Phoca-groenlandica), Can. J. Zool. Can. Zool. 73 (1995) 486-492, http:// dx.doi.org/10.1139/z95-055.

[60] Y. Espmark, R. Langvatn, Development and habituation of cardiac and behavioral responses in young red deer calves (Cervus elaphus) exposed to alarm stimuli, J. Mammal. 66 (1985) 702-711, http://dx.doi.org/10.2307/1380796.

[61] R.S. Mirza, D.P. Chivers, Predator diet cues and the assessment of predation risk by juvenile brook charr: do diet cues enhance survival? Can. J. Zool. 81 (2003) 126-132, http://dx.doi.org/10.1139/z02-225.

[62] D. Chivers, R. Mirza, Fathead minnows learn to recognize heterospecific alarm cues they detect in the diet of a known predator, Behaviour 140 (2003) 1359-1369, http://dx.doi.org/10.1163/156853903771980620.

[63] A. Mathis, R.J.F. Smith, Intraspecific and cross-superorder responses to chemical alarm signals by brook stickleback, Ecology 74 (1993) 2395-2404, http://dx.doi. org/10.2307/1939590.

[64] L.J. Roberts, C. Garcia De Leaniz, Something smells fishy: predator-naïve salmon use diet cues, not kairomones, to recognize a sympatric mammalian predator, Anim. Behav. 82 (2011) 619-625, http://dx.doi.org/10.1016/j.anbehav.2011.06.019.

[65] G.E. Brown, V.M. Dreier, Predator inspection behaviour and attack cone avoidance in a characin fish: the effects of predator diet and prey experience, Anim. Behav. 63 (2002) 1175-1181, http://dx.doi.org/10.1006/anbe.2002.3024.

[66] S. Vilhunen, H. Hirvonen, Innate antipredator responses of Arctic charr (Salvelinus alpinus) depend on predator species and their diet, Behav. Ecol. Sociobiol. 55 (2003) 1-10, http://dx.doi.org/10.1007/s00265-003-0670-8.
[67] G.E. Brown, D.P. Chivers, S.R.J. F, Fathead minnows avoid conspecific and heterospecific alarm pheromones in the faeces of northern pike, J. Fish Biol. 47 (1995) 387-393, http://dx.doi.org/10.1006/jfbi.1995.0146.

[68] R.D. Godard, B.B. Bowers, C. Wannamaker, Responses of golden shiner minnows to chemical cues from snake predators, Behaviour 135 (1998) 1213-1228.

[69] A. Moore, M.J. Ives, L.T. Kell, The role of urine in sibling recognition in Atlantic salmon Salmo salar (L.) parr, Proc. R. Soc. B Biol. Sci. 255 (1994) 173-180, http://dx.doi. org/10.1098/rspb.1994.0025.

[70] D.D. Williams, K.A. Moore, The role of semiochemicals in benthic community relationships of the lotic amphipod Gammarus pseudolimnaeus: a laboratory analysis, Oikos 44 (1985) 280, http://dx.doi.org/10.2307/3544701.

[71] P.C. Giaquinto, G.L. Volpato, Hunger suppresses the onset and the freezing component of the antipredator response to conspecific skin extract in Pintado catfish author, Behaviour 138 (2001) 1205-1214.

[72] C. Brönmark, L. Hansson, Chemical communication in aquatic systems: an introduction, Oikos 1-7 (2000)http://dx.doi.org/10.1034/j.1600-0706.2000.880112.x.

[73] S.L. Lima, Vigilance during the initiation of daily feeding in dark-eyed juncos, Oikos 53 (1988) 12, http://dx.doi.org/10.2307/3565657.

[74] C.M.D. Alvarenga, G.L. Volpato, Agonistic profile and metabolism in alevins of the Nile tilapia, Physiol. Behav. 57 (1995) 75-80, http://dx.doi.org/10.1016/00319384(94)00206-K.

[75] LJG. Barcellos, S. Nicolaiewsky, S.M.G. de Souza, F. Lulhier, Plasmatic levels of cortisol in the response to acute stress in Nile tilapia, Oreochromis niloticus (L.), previously exposed to chronic stress, Aquac. Res. 30 (1999) 437-444, http://dx.doi.org/10. 1046/j.1365-2109.1999.00348.x

[76] G.L. Volpato, R.E. Barreto, Environmental blue light prevents stress in the fish Nile tilapia, Brazilian J. Med. Biol. Res. 34 (2001) 1041-1045, http://dx.doi.org/10.1590/ S0100-879X2001000800011.

[77] LJ.G. Barcellos, S. Nicolaiewsky, S.M.G. de Souza, F. Lulhier, The effects of stocking density and social interaction on acute stress response in Nile tilapia Oreochromis niloticus (L.) fingerlings, Aquac. Res. 30 (1999) 887-892, http://dx.doi.org/10. 1046/j.1365-2109.1999.00419.x.

[78] A. Biswas, M. Maita, G. Yoshizaki, T. Takeuchi, Physiological responses in Nile tilapia exposed to different photoperiod regimes, J. Fish Biol. 811-821 (2004)http://dx.doi. org/10.1111/j.1095-8649.2004.00487.x.

[79] M.O. Fernandes, G.L Volpato, Heterogeneous growth in the Nile tilapia: social stress and carbohydrate metabolism, Physiol. Behav. 54 (1993) 319-323, http://dx.doi. org/10.1016/0031-9384(93)90117-X.

[80] D.F. Fraser, J.F. Gilliam, Nonlethal impacts of predator invasion: facultative suppression of growth and reproduction, Ecology 73 (1992) 959-970, http://dx.doi.org/10. 2307/1940172.

[81] B.L. Peckarsky, A.R. McIntosh, Fitness and community consequences of avoiding multiple predators, Oecologia 113 (1998) 565-576, http://dx.doi.org/10.1007/ s004420050410.

[82] S. Diehl, P. Eklov, Effects of piscivore-mediated habitat use on resources, diet, and growth of perch, Ecology 76 (1995) 1712-1726, http://dx.doi.org/10.2307/1940705.

[83] E.E. Werner, B.R. Anholt, Predator-induced behavioral indirect effects: consequences to competitive interactions in anuran larvae, Ecology 77 (1996) 157-169, http://dx. doi.org/10.2307/2265664.

[84] D.J. Randall, S.F. Perry, Catecholamines, in: W.S. Hoar, D.J. Randall, A.P. Farrell (Eds.), Fish Physiol., Vol XIIB, Academic Press, New York 1992, pp. 255-300.

[85] L. Hawkins, A. Magurran, J. Armstrong, Innate predator recognition in newlyhatched Atlantic salmon, Behaviour 141 (2004) 1249-1262.

[86] M.N. Fernandes, F.T. Rantin, Relationships between oxygen availability and metabolic cost of breathing in Nile tilapia (Oreochromis niloticus) : aquacultural consequences, 127 (1994) 339-346. 